\title{
STRUCTURAL FRAMEWORK OF THE ZELTEN PLATFORM, SOUTH SIRTE BASIN, LIBYA USING POTENTIAL FIELDS MODELLING
}

\author{
Abdelhakim ESHANIBLI ${ }^{1,2)}$, Amin KHALIL ${ }^{3)}$ *, \\ Abdellatif YOUNIS ${ }^{4)}$ and Hussin GHANOUSH ${ }^{2)}$ \\ 1) School of Physics, University Sains Malaysia, Pulau Penang, 11800, Malaysia \\ 2) Libyan Petroleum Institute (LPI), Tripoli, 6431, Libya \\ 3) Geology Department, Faculty of Science, Helwan University, Cairo, 11795, Egypt \\ 4) National Research Institute of Astronomy and Geophysics, NRIAG, Helwan, Cairo,11421, Egypt \\ *Corresponding author's e-mai:aminwej@gmail.com
}

\section{ARTICLE INFO}

Article history:

Received 30 January 2020

Accepted 21 May 2020

Available online 24 June 2020

Keywords:

Magnetic anomaly

Gravity anomaly

Geologic structure

Zelten platform

Sirt basin

\begin{abstract}
Integration between magnetic and gravity data at the Zelten platform, the southeast part of Sirt Basin Libya. Zelten Platform is first discovered oil field in Libya. It shows numerous geological structures of different tectonic events. The methods adopted can assist in locating the hidden subsurface structures. The platform is characterized by the NW-SE trending rift that belongs to the Early Cretaceous age (during the collapse of Sirt Arch). The study aimed to define the structural geology that assisted in the development of future exploration in this area. The analyses utilized several filtering and transformation algorithms to help in structural modeling. For instance, the total horizontal gradient and tilt angle derivative were applied for the edge detection of the tectonic boundaries. The results show NW-SE and NNW-SSE patterns that represents faults that controlled the positions of the troughs and platforms at the Sirt basin. On the other hand, Euler deconvolution and 2D forward modeling were utilized to determine the depth of the basement. The Integrated models deduced revealed that the main faults trends are NW-SE which refer to the rift phases and crustal extension period that occurred during the Mesozoic time (early cretaceous). Also, the basement depth ranges from $6.5 \mathrm{~km}$ to $8 \mathrm{~km}$ according to the structures that affected the study area.
\end{abstract}

\section{INTRODUCTION}

Magnetic and gravity techniques have been integrated to map both shallow and deep structures that control the structural framework of the Zelten platform. The platform is probably associated with reactivated rift faults and the main rifting phases that occurred in the Sirt Basin (Burke and Dewey, 1973). The area of study comprises the first hydrocarbon discovery in Libya. The understanding of the structural framework may help in the pointing out potentials for more oil reserve there.

The study area is Zelten platform that lies between longitudes $19^{\circ} 30$ and $20^{\circ} 00 \mathrm{E}$ and latitudes $29^{\circ} 00$ and $29^{\circ} 50 \mathrm{~N}$ (Fig. 1). It belongs to the south-east part of the Sirt Basin and characterized by NW-SE trending structures, which reflect the major rift faults (Harding, 1984). Also, the platform is considered as one of the most significant tectonic units of the Sirt Basin (Fraser, 1967). The study area is bounded by the Jahamah platform to the north, Ajdabiya trough and Assumud ridge to the northeast, and the southern shelf to the south. The significant structural elements in the study area are the major Northwest-Southeast trending normal faults, which extended along the south part of the area (Harsha and Owaina, 2000). Results from previous magnetic and gravity studies in Sirt Basin have been reported by several authors (Essed, 1978; EL-Batroukh and Zentani, 1980; Nyblade et al., 1996). The major highlight is that magnetic and gravity anomalies in the whole of the Sirt Basin have been significantly affected by the magmatism developed during the early Cretaceous-Tertiary. This magmatism is a result of the crustal extension which created active subsidence following the collapse of post-Hercynian structures (van der Meer and Cloetingh, 1993; Hallett, 2002).

Geophysical methods have been utilized over the last decade to define the structures in the whole of Sirt Basin, of which Zelten platform a part of it (Elakkari, 2005; Saheel et al., 2010; Ghanoush et al., 2014; Ghanoush, 2019) This study, therefore, aims to integrate geological information, gravity and magnetic data to define the structural features and the depth to basement rocks of the study area. The choice of gravity and magnetic methods was based on their ability to determine the subsurface structures at deeper depths.

\section{GEOLOGIC AND TECTONIC SETTINGS}

In the early Paleozoic and following Pan-African orogeny, massive deposits were accumulated within 


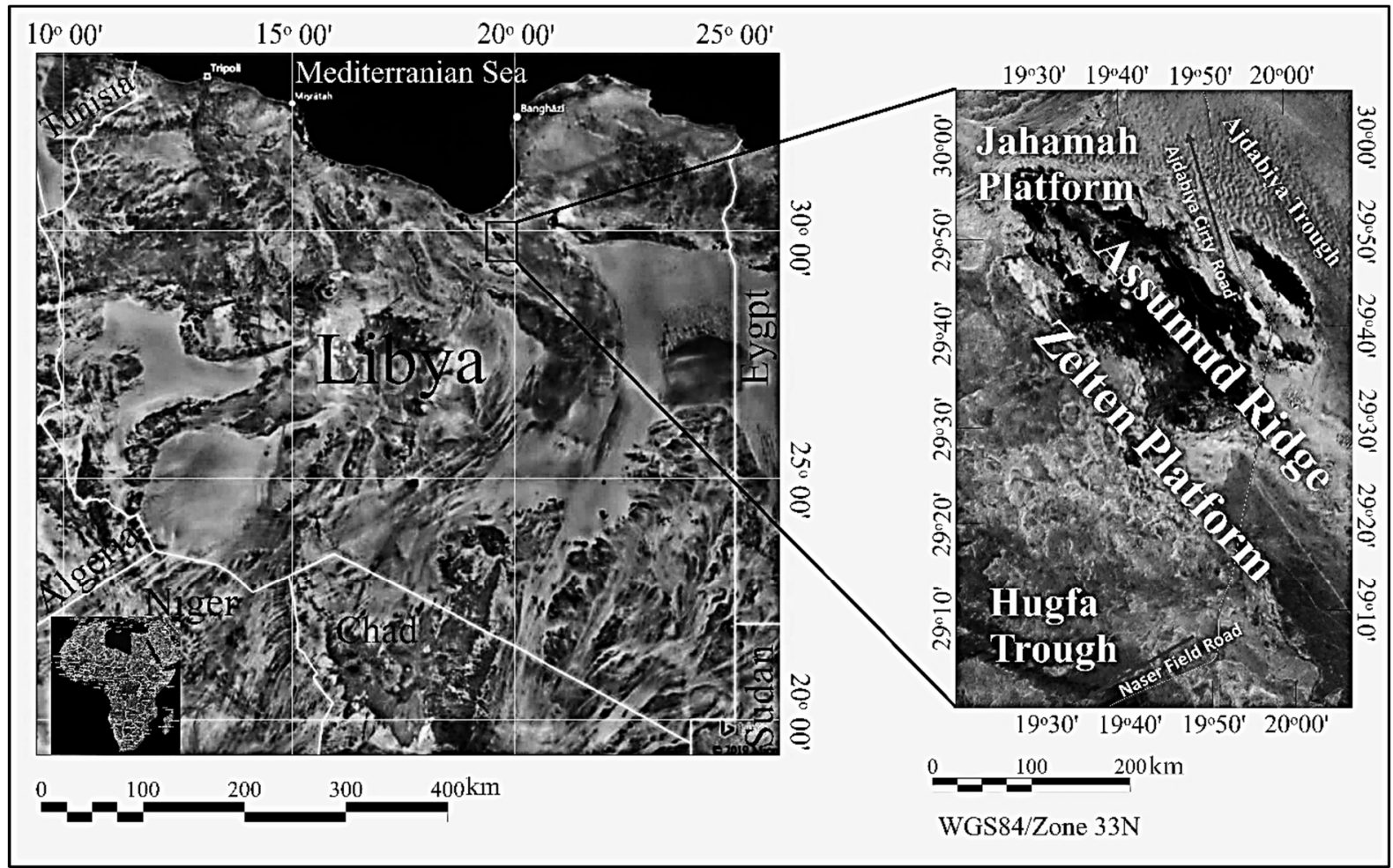

Fig. 1 Tectonic map of Libya illustrating regional and local structures. The area of study is the Zelten platform.

Kalanshiyu Trough in the northeast of the Sirt basin (Hallett, 2002; 2017). Breaking-up of Pangea commenced in the Triassic. Besides, this period was accompanied by a rifting period that occurred in Libya and Tunisia during the Upper Triassic (van der Meer and Cloetingh, 1993; Abadi et al., 2008). The Hercynian orogeny began at the late of Carboniferous and continued to Early Permian (400-280Ma) causing a broad arching area within the Sirt Basin (El-Arnauti et al., 2008). Basement rocks in Libya, especially in the Sirt basin, are regarded as Paleozoic structures with NE-SW, N-S, and E-W trends. Nevertheless, block faulting took place (Fig. 2) along NNW-SSE to NW-SE zone (Anketell, 1996; Bumby and Guiraud, 2005). The Tethyan sea was opened through the late Jurassic and continued to early Cretaceous (de Lamotte et al., 2004). The Sirt Basin was formed from the residue of the northern part of the Sirt Arch which collapsed during early Cretaceous into five main grabens (Fig 2), namely; "Hun, Maradah, Zellah, Hameimat, and Ajdabiya" (Gumati and Kanes, 1985). These grabens have an orientation NNW-SSE and NW-SE. The Sirt Basin was kept the same structural framework throughout until Late Cretaceous and Paleocene (Barr and Weegar, 1972; Saleem, 2015).

During the Late Cretaceous to early Paleocene time, the basin subjected to a reactivation process. The major structural features in the Sirt basin show sedimentation pattern with NW-SE trending structures. This feature is represented by the Dahra platform and Zellah trough in the west part of the basin, the Bayda platform in the central region, Ajdabiya trough at the northeast, and Zelten platform in the southeast part of the basin (Anketell, 1996; Abuhajar and Roohi, 2003).

The rifting phase started during the early Cretaceous and Culminating at the end of the Cretaceous and ended during the early Tertiary time, causing the tripartite junction between Tibesti, Sarir arms, and Sirt basin (Harding, 1984; Gras, 1996; Ambrose, 2000). The fault zone within the Sirt basin caused to form a group of NW-SE and NNW-SSE faults which controlled the place of the troughs and platforms at the basin (Wennekers et al., 1996). The final tectonic phase started during the Oligocene and is characterized by an N-S trend fault. Besides, the Ajdabiya trough persisted in subsiding (Hallett, 2002).

\section{MATERIAL AND METHODOLOGY:}

In the present work, potential field data were collected for the purpose of determining the structural pattern at the study area. The processing techniques chosen for that purpose are widely used to achieve the objectives of the present work. For instance, both tilt angle and total gradients are useful as an edge detection technique for the delineation of the structural trends. Euler deconvolution and 2D forward modelling, on the other hand, is useful for the delineating the vertical extents of the structures. The use of both groups of techniques is useful for building an integrated structural model. The structural model will help to achieve the objectives of the study.

\subsection{POTENTIAL FILED DATA}

The gravity dataset for the land survey was obtained from the Libyan Petroleum Institute (LPI) in 


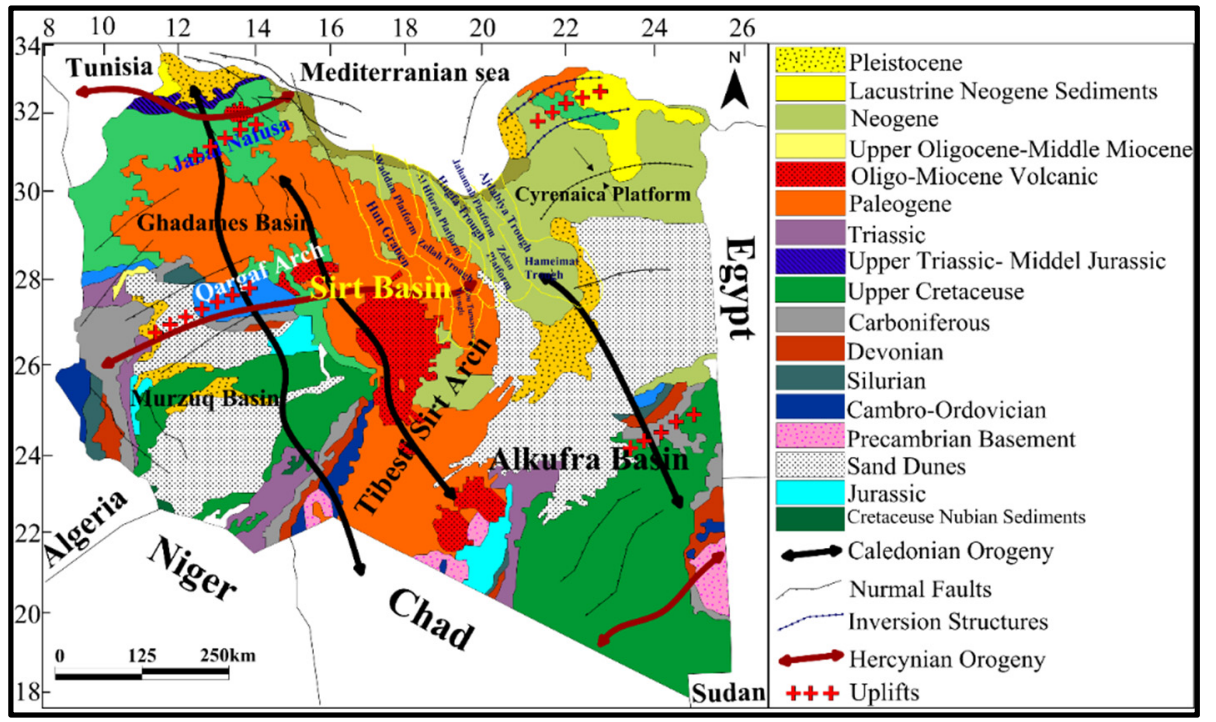

Fig. 2 Simplified geological map of Libya showing the main platforms and troughs produced by the rifting on the Sirt Basin.

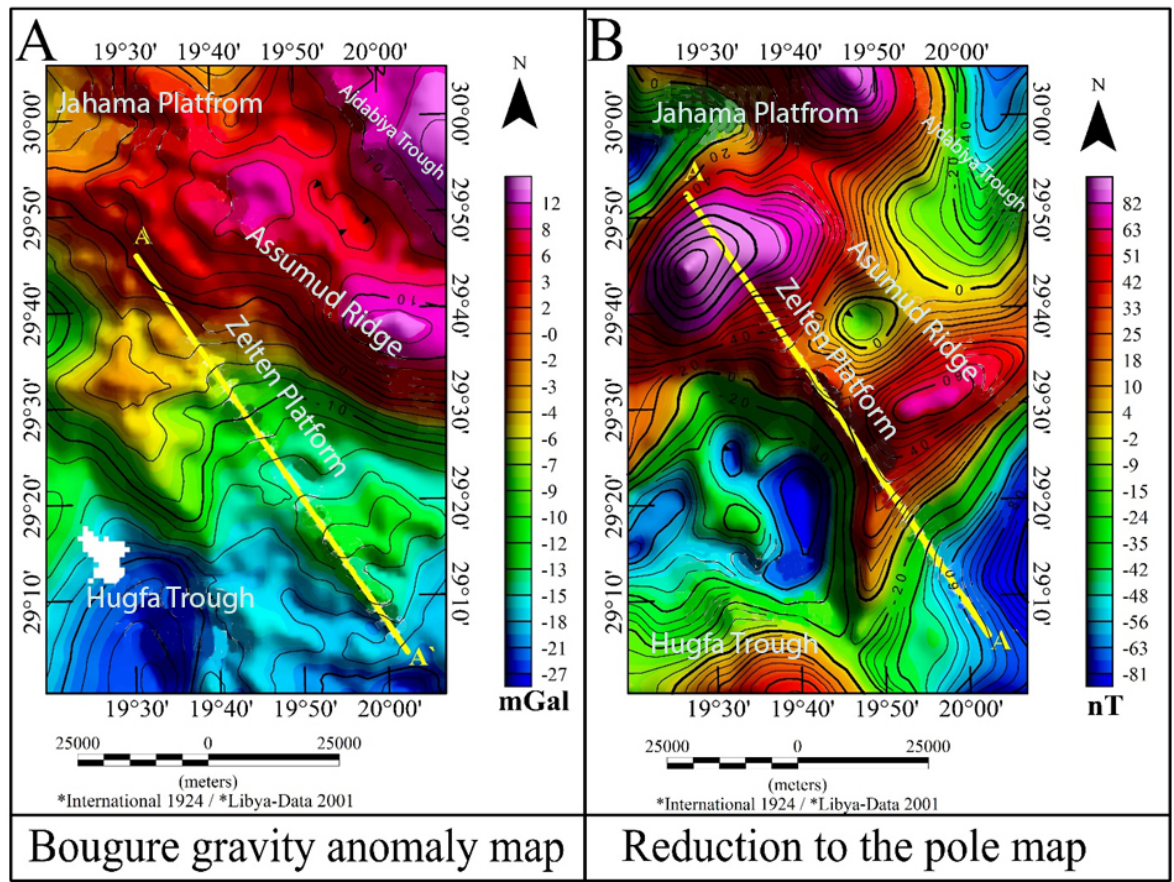

Fig. 3 Maps of potential field data used in the present study, the yellow line is profile (A $\left.-A^{\prime}\right)$ for modelling.

Tripoli, Libya which has ties to the Libyan Gravity Project LGP (Saleem, 2015). The LGP collects data from numerous oil and gas companies working in Libya and the National Oil Corporation (NOC). Land gravity points dataset was tied to the Geodetic Reference System 1980 (GRS 80) (Moritz, 1984). The gravity dataset gridded to $1.0 \mathrm{~km}$ relied on the natural distribution of the gravity data points and reduced density of $2.67 \mathrm{~g} / \mathrm{cm}^{3}$ to produce the final Bouguer gravity map (Fig. 3-A). This gravity dataset has an accuracy around $\pm 0.10 \mathrm{mGal}$

Aeromagnetic data is obtained from the African magnetic mapping project AMMP. The AMMP collects all available airborne, ground and marine magnetic data for the whole of Africa (Getech, 2000). The magnetic data, which consists of different resolutions, are consolidated into a unified $1 \mathrm{~km}$ grid at a constant $1 \mathrm{~km}$ elevation above the terrain. The total magnetic intensity (TMI) map was produced by deducting the International Geomagnetic Reference Field "IGRF" at all the stations (Barraclough and Malin, 1971), and reduced to the pole to obtain the Reduction to the Pole (RTP) map (Fig. 3-B) by applying the fast Fourier transform (FFT) as embedded in Oasis Montaj Programs, (2015) and magnetic field parameters at this location (inclination $\mathrm{I}=41.23^{\circ}$ and declination $\mathrm{D}=1.75^{\circ}$ ). 


\subsection{SOURCE EDGE DETECTION HORIZONTAL GRADIENT METHOD}

The Total Horizontal Gradient (HG) is a standard method applied to both gravity and magnetic data. When employed to gravity data, the HG helps to locate the density boundaries and define the geological contacts (Cordell, 1979; Cordell and Grauch, 1985; Blakely, 1995; Pham et. al, 2019). On the other hand, the HG method is applied to magnetic data to delineate the susceptibility boundaries (Cordell, 1979; Blakely, 1995). The magnitude of the horizontal gradient $\operatorname{HG}(x, y)$ is a function of both $\mathrm{x}$ and $\mathrm{y}$ derivatives (Cordell and Grauch, 1985). This means that the magnitude depends on the surface but not the thickness of the causative body.

\section{- $\quad$ Tilt Angle Derivative}

Miller and Singh (1994), Ejiga et. al. (2019) and Nguyen et. al. (2019) introduced the tilt angel derivative to discern the potential field anomaly of causative source edges based on a combination of the horizontal and vertical derivatives of the potential field data. The tilt angle is the ratio of the vertical derivative to the total horizontal derivative, which can be expressed as:

$$
T A=\tan ^{-1}\left(\frac{\partial g / \partial z}{\sqrt{\left(\frac{\partial g}{\partial x}\right)^{2}+\left(\frac{\partial g}{\partial y}\right)^{2}}}\right)
$$

where $g$ is the gravity or magnetic anomaly, $\frac{\partial g}{\partial x}, \frac{\partial g}{\partial y}$ and $\frac{\partial g}{\partial z}$ are the partial derivative of $g$ in the $x, y$ and $z$ directions, respectively.

The tilt angle value over the source is positive when the density contrast of the causative mass is positive and negative outside the source limits. The tilt angle ranges between $-90^{\circ}$ and $+90^{\circ}$, and as a result, Cooper and Cowan (2006) argue that it is much easier to interpret than the analytic signal phase angle. The tilt angle is comparatively insensitive to the depth of the source. This study applied the technique to both gravity and magnetic data to define the subsurface structures.

\subsection{EULER 3-D DECONVOLUTION}

Euler deconvolution (Thompson, 1982; Reid et al., 1990; de Melo and Barbosa, 2017; Reid et al., 2014; Usman et. al., 2018; Essa et. al., 2020), is an automatic interpretation technique utilized for potential field data. Initially developed by Thompson (1982) to analyze small 2-D profile data. The method uses the potential field anomaly and its derivatives combined with a given structural index to assess the position parameters of the anomaly source. Later, Reid et al. (1990) developed the technique for 3-D gridded data. The 3-D Euler deconvolution technique was used to delineate geological boundaries based on the difference between magnetization or density (Marson
Table 2 Structural Index (SI) for gravity and magnetics (Reid et al., 1990).

\begin{tabular}{lcc}
\hline Source & Gravity & Magnetic \\
\hline Sphere & 2 & 3 \\
Horizontal & 1 & 2 \\
Fault & 0 & 1 \\
Contact & & 0 \\
\hline
\end{tabular}

and Klingele, 1993). Moreover, the technique is usually utilized for gravity and magnetic data. In this study, Euler deconvolution was implemented on the gravity data with an accuracy of the mapped sources of about +/- $20 \%$ (Reid et al., 1990). The 3-D form of the Euler deconvolution equation is expressed as follow:

$$
\begin{gathered}
\left(x-x_{0}\right) \frac{\partial F}{\partial x}+\left(y-y_{0}\right) \frac{\partial F}{\partial y}+\left(z-z_{0}\right) \frac{\partial F}{\partial z}= \\
=N(B-F)
\end{gathered}
$$

where $\boldsymbol{F}$ is the potential field data $x, y$, and $z$ are the coordinates of the known points of measurements, $x_{0}$, $y_{0}$ and $z_{0}$ are the unknown source coordinates, $B$ is the background field, and $N$ is the structural index (SI) that describes the nature of the causative source (Reid et al., 1990; Stavrev, 1997). Table 1 lists the values of SI as a function of source types. For gravity data, the parameters used for Euler deconvolution of are $(\mathrm{SI}=0$, window size $8 * 8$ and max tolerance depth $18 \%$ ), while for the magnetic are $(\mathrm{SI}=1$, window size $8 * 8$ and max tolerance depth $18 \%$ )

\section{RESULTS AND DISCUSSIONS: \\ 4.1. QUALITATIVE ANALYSIS}

The Bouguer gravity anomaly map (Fig. 3-A) indicates low anomalies in the southern part of the study area with values ranging from $-27 \mathrm{mGal}$ to - $2 \mathrm{mGal}$, whereas the northern part with a high amount around $8 \mathrm{mGal}$. The gravity values in most parts of the region are changing gradually except for the northwest portion. The anomaly there shows a sharp contrast, which may be indicative of a rapid change in the subsurface structure. The Bouguer anomaly map shows two major zones anomaly ranging from low anomaly at the southeast to high anomaly in the northwest portion of the study area.

The RTP map (Fig. 3B), on the other hand, shows negative magnetic anomalies with values ranging from -9 to $-81 \mathrm{nT}$ that are observed over the south part of the Zelten platform, Jahamah platform, and the southern part of Ajdabiya trough. High amplitudes characterize these negative anomalies, whereas the central and north part of the Zelten platform, are characterized by positive anomalies around 25 to $82 \mathrm{nT}$. These magnetic anomalies indicate the presence of two faults trending NW-SE and NNE- SSW cut by an N-S trend in the south part of Ajdabiya trough. 


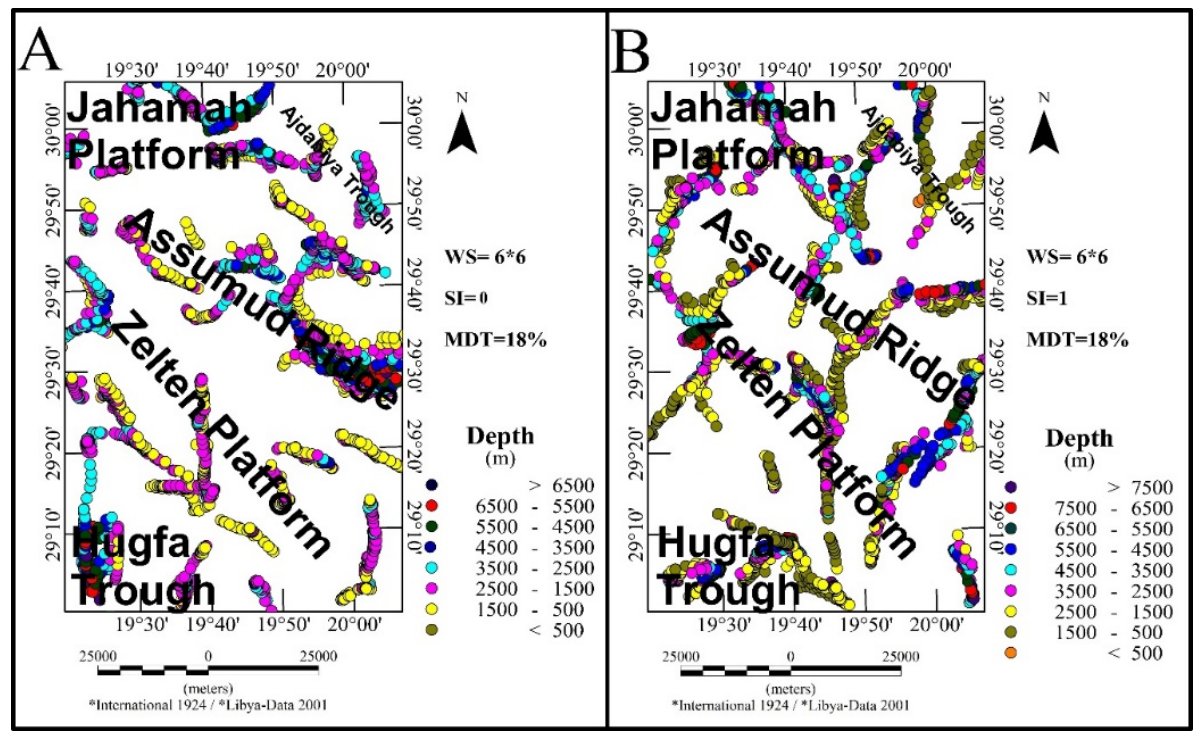

Fig. 4 3D Euler's deconvolution solution A- Euler solution of gravity data, B Euler solution of magnetic data.

\subsection{EULER 3D SOLUTION}

3D Euler has been implemented on gravity and magnetic data in this study area to delineate the depth to the geologic sources which generate the observed anomalies on the gravity anomaly map. The results have plotted for both gravity and magnetic data. The result of Euler gravity solutions is shown in Figure 4- A. The solutions are of different source depths ranging from $500 \mathrm{~m}$ to $6500 \mathrm{~m}$. In the Zelten platform, the Euler solutions show the depth of sources ranging from $2500 \mathrm{~m}$ to $5500 \mathrm{~m}$ with orientations of NW-SE and N-S trend. The Euler solution of magnetic data (Fig. 4-B) shows the depth of sources ranging from $500 \mathrm{~m}$ to $7500 \mathrm{~m}$; however, in the study area, the solutions have a depth ranging from $2500 \mathrm{~m}$ in the south of the region to $6500 \mathrm{~m}$ in the northwest with orientations of N-S an NNW-SSE.

\subsection{SOURCE EDGE DETECTION SOLUTIONS}

The maps in Figure 5-A presents the horizontal gradient of gravity anomaly which refer to NW-SE strong gradient at the Zelten platform, northwest of Hugfa trough and Assumud ridge which may refer to the crustal extension which occurred in the early Cretaceous (Hallett, 2002), whereas the horizontal gradient of magnetic (Fig. 5-B) shows N-S and NNE- SSW which refers to the evolution of the Paleozoic structures trending "basement rocks" (Anketell, 1996). The NW-SE and NNW-SSE are the faults that controlled the location of the troughs and platforms at the Sirt basin (Wennekers et al., 1996).

The Tilt angle of gravity and magnetic anomaly (Figs. 6 -A,B) present the zero contour of title angle trend locate along boundaries of anomalies and along the fault's longitudinal orientation NW-SE in the Figure 7-A which represents the tilt angle of gravity anomaly while the tilt angle of magnetic anomaly show different fault direction which can be divided into 2 groups as follow:
1. NNW-SSE in the northern part of the Zelten platform.

2. NE-SW at Assumud ridge.

\subsection{FORWARD MODELING}

The magnetic and gravity anomalies have been modeled to get the best fit between calculated and observed magnetic and gravity by applying the 2D forward modeling. The methods are used to calculate the gravity and magnetic responses based on the formulations by Talwani et al. (1959). The 2D modelling was conducted using the GM-SYS software, which is an extension of the Oasis montaj software package. The initial model parameters were deduced from previous work performed in the neighborhood of the study region.

The modelling was conducted to delineate the basement relief of underneath the Zelten area.

For this purpose, the grids for both gravity and magnetic data were profiled at A-A' as shown in Figure 3. The profile is taken perpendicular to the main anomalies that is related to the Assumud ridge. Such choice may give a representative model for the basement relief at the study area. The depth to the basement is changing from the NW to the SE of the profile used for the modelling. The depth change follows the change of both gravity and magnetic anomalies. The anomalies shows high values at the NW that decreases gradually to the SE. The change may be attributed to either the change of the depth to the basement or the presence of massive intrusion at the NW side. From the geologic information available to this research, the depth relief of the basement is favoured. Accordingly, the model shown in Figure 7 represents a shallower basement at the NW side and a deeper basement at the SE side. For instance, the depth to the basement at the NW reaches almost $6500 \mathrm{~km}$, while at the SE the depth os around $8000 \mathrm{~km}$. 


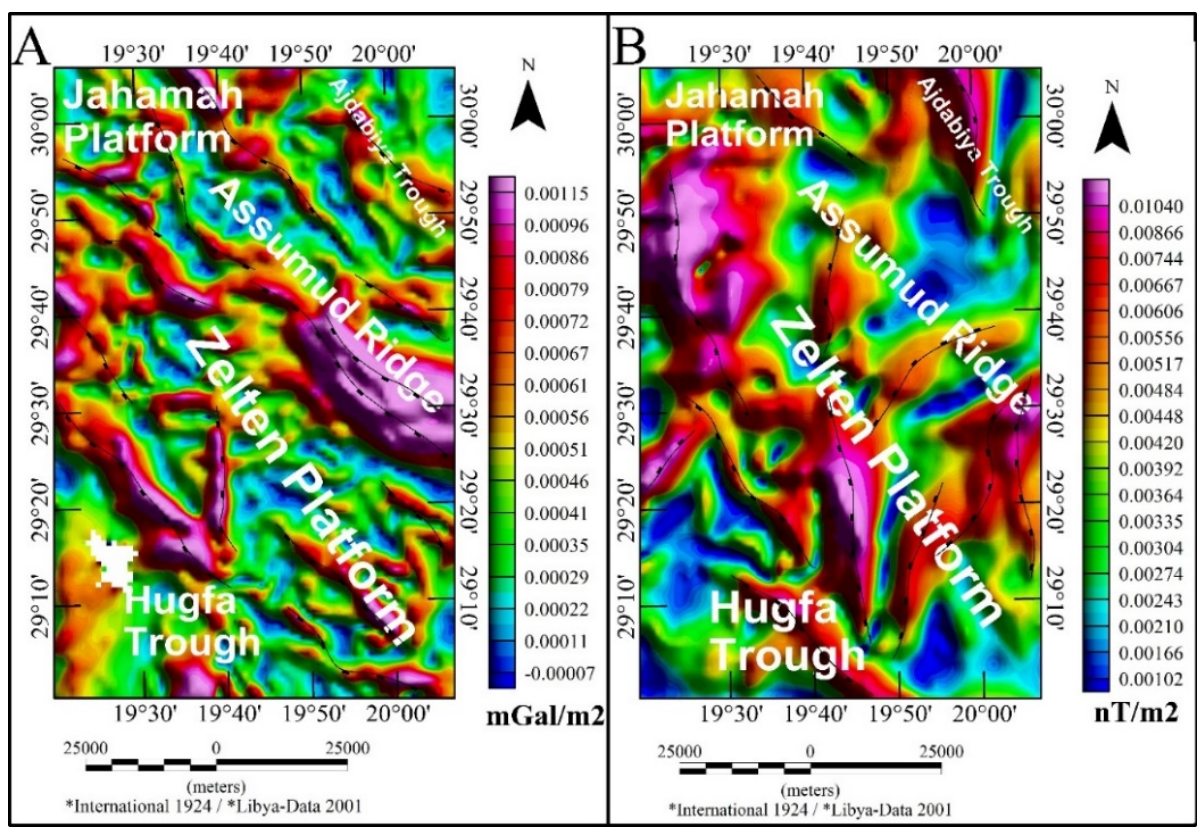

Fig. 5 Total horizontal gradient map A-HG of gravity anomaly, B- HG of the magnetic anomaly. Peaks (zones of Pink color) marks the geologic boundaries or fault locations.

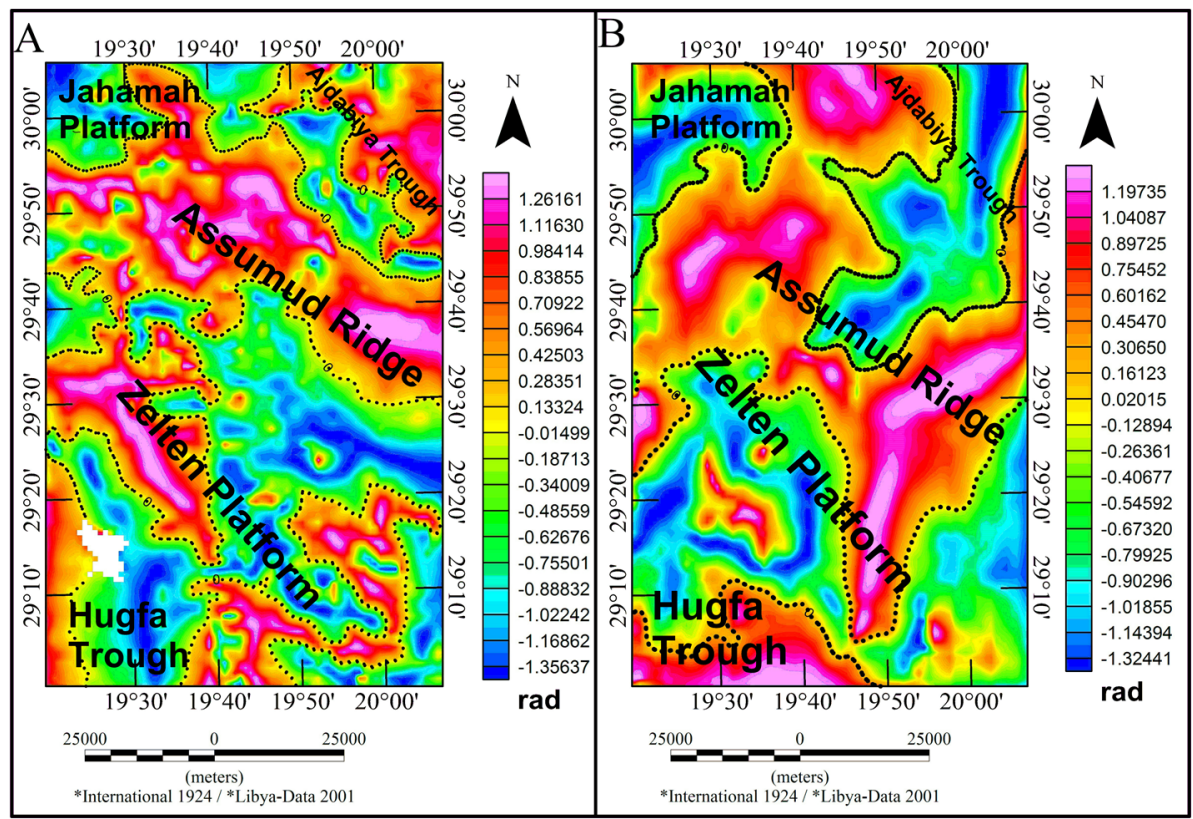

Fig. 6 Tilt angle Derivative A- Tilt angle of Gravity anomaly, B- Tilt angle of Magnetic anomaly. The zero contour is plotted in both solid and dotted lines. The contour represents the boundaries of the causative bodies.

\section{CONCLUSION}

The structural pattern and depth relief of the basement are the main objectives of the present work. Both magnetic and gravity field data for the Zelten area were analysed and modelled to get the desired model. As the magnetic and gravity anomalies are directly related to the contacts between masses of different density and or magnetic susceptibility, these methods are good for the structural modelling. Geologically, the Zelten platform is located at the south of the Sirte basin and is bounded by the Jahamah platform to the north, Ajdabiya trough and Assumud ridge to the northeast, and the southern shelf to the south. The analysis showed that the faultings are generally trending NW-SE to N-S. This is obtained from the tilt angle algorithm and the total horizontal gradient of magnetic and gravity anomalies. The structural depths were obtained using the 3-D Euler deconvolution and the 2-D forward modelling. The results from the Euler deconvolution are helpful to determine the structural evolution of the study area. Besides, the 2-D forward modelling was helpful in the determination of the basement relief. The latter shows that the sedimentary section is thickening to the SE 


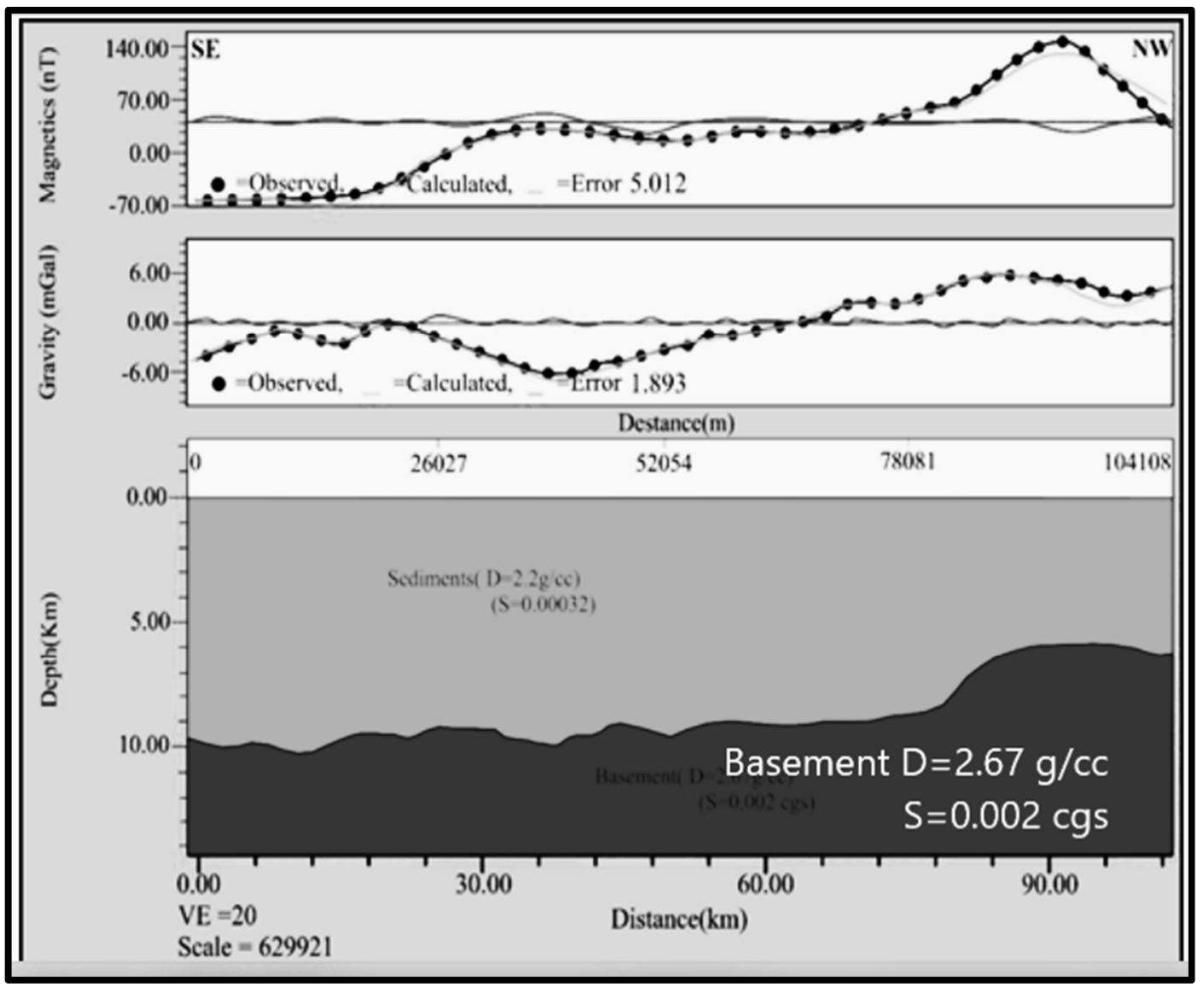

Fig. 7 NW-SE gravity and magnetic A-A` model form Zelten platform.

side of the Zelten platform. This may indicate more potential for hydrocarbon source rock and basin there.

The results obtained was valuable for the determination of the structural framework at the study area. However, more data are required to evaluate the potential of hydrocarbon shows efficiently. Examples of data required are well logs and seismic sections. An integral second phase of study is needed to delineate the hydrocarbon plays in the area.

\section{REFERENCES}

Abadi, A.M., van Wees, J.-D., van Dijk, P.M. and Cloetingh, S.A.: 2008, Tectonics and subsidence evolution of the Sirt Basin, Libya. AAPG Bulletin, 92, 8, 993-1027. DOI: $10.1306 / 03310806070$

Abuhajar, M.I. and Roohi, M.: 2003, Giant fields in the Sirt Basin, Libya. Proc. of the 1st EAGE North African Mediterranean Petroleum \& Geosciences Conference \& Exhibition, Oct. 2003.

DOI: 10.3997/2214-4609-pdb.8.S025

Ambrose, G.: 2000, The geology and hydrocarbon habitat of the Sarir Sandstone, SE Sirt Basin, Libya. J. Pet. Geol., 23, 2, 165-192.

DOI: $10.1111 / \mathrm{j} .1747-5457.2000 . t b 00489 . x$

Anketell, J.M.: 1996, Structural history of the Sirt basin and its relationship to the Sabrata basin and Cyrenaica platform, northern Libya. In: The Geology of the Sirt basin, III, 57-89.

Barr, F.T. and Weegar, A.A.: 1972, Stratigraphic nomenclature of the Sirte Basin, Libya. The Petroleum Exploration Society of Libya, Tripoli.
Barraclough, D.R. and Malin, S.R.C.: 1971, Synthesis of international geomagnetic reference field values: HM Stationery Office.

Blakely, R.: 1995, Potential theory in gravity and magnetic applications. Cambridge University, Cambridge. DOI: $10.1017 / \mathrm{CBO} 9780511549816$

Bumby, A.J. and Guiraud, R.: 2005, The geodynamic setting of the Phanerozoic basins of Africa. J. Afr. Earth Sci., 43, 1-3, 1-12. DOI: 10.1016/j.jafrearsci.2005.07.016

Burke, K. and Dewey, J.F.: 1973, Plume-generated triple junctions: key indicators in applying plate tectonics to old rocks. J. Geol., 81, 4, 406-433. DOI: $10.1086 / 627882$

Cooper, G.R.J. and Cowan, D.R.: 2006, Enhancing potential field data using filters based on the local phase. Comput. Geosci., 32, 10, 1585-1591. DOI: 10.1016/j.cageo.2006.02.016

Cordell, L. and Grauch, V.: 1985,. Mapping basement magnetization zones from aeromagnetic data in the San Juan Basin, New Mexico. Society of Exploration Geophysicists, The utility of regional gravity and magnetic anomaly maps, 181-197. DOI: $10.1190 / 1.0931830346 . c h 16$

Cordell, L.: 1979, Gravimetric expression of graben faulting in Santa Fe Country and the Espanola Basin, New Mexico. New Mexico Geological Society, $30^{\text {th }}$ Annual Fall Field Conference Guidebook.

de Lamotte, D.F., Crespo-Blanc, A., Saint-Bézar, B., Comas, M., Fernandez, M., Zeyen, H. and Zizi, M.: 2004, Transect I: Iberian Meseta-Guadalquivir BasinBetic Cordillera-Alboran Sea-Rif-Moroccan Meseta-High Atlas-Sahara Platform. The Transmed 
Atlas: The Mediterranean Region from Crust to Mantle, Springer, Berlin, 141.

de Melo, F.F. and Barbosa, V.C.F.: 2017, What to expect from Euler deconvolution estimates for isolated sources. In: 15th International Congress of the Brazilian Geophysical Society \& EXPOGEF, Rio de Janeiro, Brazil, 31 July-3 August 2017, Brazilian Geophysical Society, 1092-1097.

Ejiga, G.E., Yusoff, I., Ismail, N.E.H. and Usman, U.A.: 2019, Utilizing the magnetic source edge detection (MSED) method in mapping geologic features within a sedimentary basin. Warta Geologi, 45, 3 .

Elakkari, T.S.: 2005, Structural configuration of the Sirt basin, MSc.Thesis.

El-Arnauti, A., Lawrence, S.R., Mansouri, A.L., Şengör, A.M.C., Soulsby, A. and Hassan, H.: 2008, Structural styles in NE Libya. Geology of East Libya, 4, 153178.

El-Batroukh, S.I. and Zentani, A.: 1980, Gravity interpretation of Raguba field, Sirte basin, Libya. Geophysics, 45, 7, 1153-1163.

Essa, K.S., Elhussein, M. and Youssef, M.A.: 2020, Magnetic data interpretation using advanced techniques: A comparative study. In: Advances in Modeling and Interpretation in Near Surface Geophysics, Springer, Cham, 263-294.

Essed, A.S.: 1978, A reconnaissance Bouguer Gravity Anomaly Map of Libya. MSc. Thesis, Purdue University.

Fraser, W.W.: 1967, Geology of the Zelten Field. Libya, North Africa. Paper presented at the 7th World Petroleum Congress, 2-9 April 1967, Mexico City, Mexico.

Getech, J.S.Z.: 2000, Libya: a tectonic and depth-tobasement study using well, gravity and magnetic data. Unpublished report (G0030).

Ghanoush, H., Imber, J. and McCaffrey, K.: 2014, Cenozoic subsidence and lithospheric stretching deformation of the Ajdabiya Trough Area, Northeast Sirt Basin, Libya. Paper presented at the AAPG 2014 Annual Convention and Exhibition, Houston, Texas.

Ghanoush, H.: 2019, Structure of the Ajdabiya Trough, NE Sirt Basin Libya, derived from gravity and magnetic data. Int. J. Sci. Res., 8, 3. DOI: $10.21275 /$ ART20195738

Gras, R., 1996. Structural style of the southern margin of the Messlah High. In: Salem, M.J., El-Hawat, A.S., Sbeta, A.M. (Eds.), The Geology of Sirte Basin II. Elsevier, Amsterdam, 201-210.

Gumati, Y.D. and Kanes, W.H.: 1985, Early Tertiary subsidence and sedimentary facies--northern Sirte Basin, Libya. AAPG Bulletin, 69, 1, 39-52. DOI: 10.10306/AD461B83-16FZ-11D7-8645000102C1865D

Hallett, D.C.-L.: 2002, Petroleum geology of Libya, Elsevier, Amsterdam, The Netherlands, $508 \mathrm{pp}$.

Hallett, D.C.-L.: 2017, Petroleum geology of Libya: Elsevier, Amsterdam, The Netherlands.

Harding, T.P.: 1984, Graben hydrocarbon occurrences and structural style. AAPG Bull., 68, 3, 333-362. DOI: 10.1306/AD460A21-16FZ-11D7-8645000102C1865D

Harsha, S.M. and Owaina, F.: 2000, Seismic interpretation of Gargaf Group Palaeostructures, NW of Concession 6, Sirte Basin, Libya. J. Petrol. Res., 12, 18-24.

Marson, I. and Klingele, E.E.: 1993, Advantages of using the vertical gradient of gravity for 3-D interpretation. Geophysics, 58, 11, 1588-1595.

DOI: $10.1190 / 1.1443374$
Miller, H.G. and Singh, V.: 1994, Potential field tilt-a new concept for location of potential field sources. J. Appl. Geophys., 32, 2-3, 213-217.

DOI: 10.1016/0926-9851(94)90022-1

Moritz, H.: 1984, Geodetic reference system 1980. Bull. Geod., 58, 3, 388-398.

Nguyen, H.H., Van Dang, L. and Van Vo, V.: 2019, A combined Euler deconvolution and tilt angle method for interpretation of magnetic data in the South region. Science and Technology Development Journal, 22, 2, 219-227.

Nyblade, A.A., Suleiman, I.S., Roy, R.F., Pursell, B., Suleiman, A.S., Doser, D.I. and Keller, G.R.: 1996, Terrestrial heat flow in the Sirt Basin, Libya, and the pattern of heat flow across northern Africa. J. Geophys. Res., Solid Earth, 101, B8, 17737-17746. DOI: 10.1029/96JB01177

Oasis Montaj Programs: 2015, Geosoft Mapping and Processing System: Inc Suit 500, Richmound St. West Toronto, ON Canada N5SIV6

Pham, L.T., Oksum, E. and Do, T.D.: 2019, Edge enhancement of potential field data using the logistic function and the total horizontal gradient. Acta Geod. Geophys., 54, 1, 143-155. DOI: $10.1007 / \mathrm{s} 40328-019-00248-6$

Reid, A.B., Allsop, J.M., Granser, H., Millett, A.J. and Somerton, I.W.: 1990, Magnetic interpretation in three dimensions using Euler deconvolution. Geophysics, 55, 1, 80-91. DOI: 10.1190/1.1442774

Reid, A.B., Ebbing, J. and Webb, S.J.: 2014, Avoidable Euler errors-the use and abuse of Euler deconvolution applied to potential fields. Geophys. Prospect., 62, 5 , 1162-1168. DOI: 10.1111/1365-2478.12119

Saheel, A.S., Samsudin, A.R. and Hamzah, U.: 2010, Regional geological and tectonic structures of the Sirt Basin from potential field data. Am. J. Sci. Ind. Res., $1,3,448-462$. DOI: 10.5251/ajsir.2010.1.3.448.462

Saleem, M.A.A.: 2015, Tectonic evolution and structural analysis of south-western Sirte Basin, Central Libya. University of Birmingham, Thesis.

Stavrev, P.Y.: 1997, Euler deconvolution using differential similarity transformations of gravity or magnetic anomalies. Geophys. Prospect., 45, 2, 207-246. DOI: 10.13140/2.1.3210.0489

Talwani, M., Lamar, J. and Landisman, M.: 1959, Rapid gravity computations for two-dimensional bodies with application to the Mendocino submarine fracture zone J. Geophys. Res., 64, 1, 49-59. DOI: 10.1029/JZ064i001p00049

Thompson, D.T.: 1982, EULDPH: A new technique for making computer-assisted depth estimates from magnetic data. Geophysics, 47, 1, 31-37. DOI: $10.1190 / 1.1441278$

Usman, N., Abdullah, K., Nawawi, M. and Khalil, A.E.: 2018, New approach of solving Euler deconvolution relation for the automatic interpretation of magnetic data. Terr. Atmos. Oceanic Sci., 29, 3. DOI: 10.3319/TAO.2017.10.05.01

van der Meer, F.D. and Cloetingh, S.A.P.L.: 1993, Intraplate stresses and the subsidence history of the Sirte Basin, Libya. Tectonophysics, 226, 1-4, 37-58. DOI: 10.1016/0040-195(93)90109-W

Wennekers, J.H.N., Wallace, F.K. and Abugares, Y.I.: 1996, The geology and hydrocarbons of the Sirt Basin: a synopsis. In: The geology of the Sirt Basin, Proc. of $1^{\text {st }}$ Symposium on the Sedimentary Basind of Libya, Tripoli, 1993, III, Amsterdam, Elsevier, 1, 3-56. 